\title{
How should a small company interact in its business network to sustain its exchange effectiveness?
}

\author{
Ariane von Raesfeld \\ Jeroen Kraaijenbrink \\ NIKOS \\ School of Management and Governance \\ University of Twente, P.O. Box 217, 7500 AE, Enschede \\ The Netherlands \\ a.m.vonraesfeldmeijer@utwente.nl
}

\begin{abstract}
This paper investigates the dynamic alignment of network and business development of two small firms in the printing industry. Developments are followed over more than 8 years. The aim of the paper is to understand how small firms can manage their network relations by maintaining both their efficiency in existing business and flexibility to develop new business. The case comparison suggests that different networking approaches drive business development. For successful business development both strong and varied ties as well as the existence of different intermediary functions of partners are necessary.
\end{abstract}




\section{Introduction}

In essence, business development refers to the entrepreneurial process of discovering, creating and exploiting opportunities (Venkataraman 1997; Shane and Venkataraman 2000; Groen 2005). As such, the business development process parallels the business market management process of understanding, creating and delivering value (Anderson and Narus 2004). To be effective in business development, companies face a twofold challenge. On the one hand, companies have to run their existing business by exploiting opportunities and delivering value. On the other hand, they need to develop new business by creating new opportunities and value. Several scholars have referred to this as the challenge of balancing exploration and exploitation (Benner \& Tushman 2003; March 1991; Lee, Lee \& Lee 2003). Where exploitation requires a company to focus on efficiently delivering value to its existing customer, exploration requires it to remain flexible in developing new business solutions.

Business development is a process that builds on the efforts of many (Anderson and Narus, 2004; Groen, 2005). The success and failure of companies depends to a large extent on their business relationships, which are connected in business networks (Håkansson 1989; Håkansson and Waluszewski 2002; Hoang and Antoncic 2003; Gadde et al. 2003). Companies face a wide range of opportunities which they often cannot realize on their own. By means of outsourcing relationships and alliances, but also by more informal forms of cooperation, companies, though, are able to expand both their explorative and exploitative actions (Koza \& Lewin, 1998; Soh \& Roberts, 2003; Faems et al., 2005; Vlaar et al. 2007). Yet, network benefits come with their costs as well (Rothaermel and Deeds 2003). Especially the setting up and maintenance of strong relationships can ask tremendous efforts and time (Granovetter 1973; 1982). Based on this duality of networks, Håkansson \& Ford (2002) have formulated three network paradoxes. When we consider the business development process in the light of these three paradoxes we can get some notion of the complexity that companies face in their everyday operation:

- "Strong relationships are the heart of a company's survival and of its growth and development. But a well-developed network of relationships also ties a company into its current ways of operating and restricts its abilities to change" (p. 250).

- "A company's relationships are the outcomes of its strategy and its actions. But the paradox is that the company is itself the outcome of those relationships and of what has happened in them. Thus a network is both a way to influence and to be influenced" ( $p$ 252).

- "Companies try to control the network that surrounds them and to manage their relationships to achieve their own aims ... the paradox is that the more a company achieves this ambition of control, the less effective and innovative will be the network" (p. 254).

Whereas large companies also face these paradoxes, they apply to small companies much stronger for two reasons (cf. Rothwell \& Dodgson 1994; 
Vossen 1998). First, networks are more important to small companies than to large companies. Small companies are more dependent on others in their network because they have fewer resources themselves. Second, small firms companies are less able to affect others exactly because they are small and typically have less power than large companies. Hence, small firms both face a higher dependency on their network and a lower ability to control that network. The success of small firms in their network is not entirely manageable nor is it entirely determined by luck and external factors. Management can make a difference, as Van de Ven et al. (1989) argued, by 'managing the odds', fostering the chances of success in times of change. Therefore, the guiding question for this study is: Facing the three paradoxes, how can a small company develop and utilize its network relations along the path of business development, such that it efficiently maintains its existing business and keeps its flexibility to develop new business?

To answer this question we will compare the networking approaches of two small software companies operating in the printing industry. Over the years, sales of both companies have grown exponential. This growth was reached through different intermediary sales partners. However, as it appeared, one was more successful than the other in exploring new opportunities with partners. In the comparison we looked at the different networking approaches the two companies used to develop their business. Our examination of the business development of the two firms shows that marketing and networking approaches specific to each firm drive the degree to which the firms were able to run their existing business in combination with developing new business.

\section{Theoretical Background}

The challenge of managing network relations

Especially when one views relationships as interconnected they are not necessarily positive to change. This is reflected in the Industrial Marketing and Purchasing perspective on networks. By relying on Social Exchange Theory, this perspective defines a business network as a set of two ore more connected business relationships. 'Connected' in this sense refers to means the extent to which "exchange in one relation is contingent upon exchange (or non-exchange) in the other relations. The connection is positive if exchange in one is contingent upon exchange in the other. The connection is negative if exchange in one is contingent upon non exchange in the other" (Cook \& Emerson 1978: 725). Viewing networks in this way, shows that interconnection generates positive and negative effects. Anderson et al. (1994) further elaborated on network effect by distinguishing between primary functions as the positive and negative effect on two partners in a dyad and secondary network functions as the indirect positive and negative effects of a relationship due to its connection to other relationships. Positive secondary effects refer to the extent to which resources, activities and actor relations in a relationship between two firms can be transferred to other 
relationships. When, however, the transfer of these three elements to other relationships is hindered, due to lock-ins in the focal relationship, the authors refer to it as negative effects.

Following this line of argument Håkansson \& Ford (2002) highlighted the three network paradoxes that were mentioned in the introduction. Based on these three paradoxes Gadde et al. (2003) drew implications for strategizing. According to these authors, even when one looks at strategizing from a single firm point of view, the heterogeneity of resources and interdependencies between activities across company boundaries, as well as cooperation among involved firms, must be considered simultaneously. A consequence of this interconnectedness is that the firm's freedom of action is restricted. On the other hand, interconnection makes it possible to mobilize relationships in change processes (Gadde et al. 2003: 362

\section{Possible networking strategies}

In this paper we lay out the differences in network strategies of two small firms in the printing industry in detail, with the aim of understanding how a small firm embedded in its network can deal with networking paradoxes when developing its business. Gadde et al. (2003) provide two general strategies, a reactive and a proactive one. They suggest that on the one hand firms who are really locked-in in their relationships, change can happen if they build on what is proposed or implemented by the counterparts. Firms in such situations act reactively to what is initiated by their relations. On the other hand, depending on the nature of its relationships, a firm can activate counterparts in the development, which is a more pro-active approach. The occupation of an information-rich position in the network is seen as an opportunity to do so.

Suggestions about what an information-rich position might imply are given by Holmen \& Pedersen (2003). They state that through the mediating functions of counterparts a firm can get a broader view of the network. Three mediating functions are introduced: a joining function enabling direct coordination; a relating function enabling coordination between the focal firm and a third party via the counterpart; an insulating function enabling coordination between the focal firm and a third party, while the two have no knowledge of each other. In fact two ideal types of intermediary functions can be distinguished, one in which integration between parties is coordinated and the other which separation between parties is maintained (see also Obstfeld 2005). The joining and relating functions refer to integration of parties, where the degree of integration is stronger in the case of joining. The isolating function refers to separation of parties by a third party.

Holmen \& Pedersen claim that in order to support a firm's strategizing, managers need to analyze and influence counterparts mediating functions. However, no suggestions are given about what this might imply for business development. Obstfeld's identification of the integrating intermediary function as a predictor of 
innovation provides further explanations for business development in a network context. Following the line of the debate about the benefits for innovation of open versus closed networks (Ahuja 2000), Obstfeld (2005) indicates that open networks with many structural holes can generate new ideas but create a coordination problem, while closed networks with dense ties provide more opportunities for coordination but might hinder the generation of new ideas. Based on this observation Obstfeld holds that integrating intermediaries are especially involved in innovation. This literature implies that: Firms, who aim to be both efficient and flexible in their network, need to have strong ties and at the same time have a broad view of their network. A broad view can be established via a variety in actor bonds, activity links and resource ties and in particular important for small firms via the intermediary functions of partners.

Combining the arguments of Holmen \& Pedersen with Obstfeld we could propose that firms who are in the phase of opportunity discovery and thus are looking for new business ideas via a variety of weak ties. These weak ties can be established via relating functions of counterparts. Thus we propose the following relationship between opportunity discovery and intermediary functions:

P1: Opportunity discovery is facilitated by relating intermediaries.

Firms who are in the phase of opportunity creation have to share resources and develop activities with different others to shape an offering which can solve customer problems. So this phase requires close cooperation between different actors. A joining intermediary can facilitate close cooperation. Thus we suggest that:

P2: Opportunity creation is facilitated by joining intermediaries

In the phase of opportunity exploitation in which an offering has to be delivered to its customers, efficiency is generated via loose cooperation. This will only work if the shape of the offering is clear, including the technology, partners and transformation and transaction activities. An isolating intermediary can facilitate such loose cooperation. Thus we propose that:

P3: Opportunity exploitation is facilitated by isolating intermediaries.

\section{Research Approach}

The analysis draws on a comparison of two case studies (Yin, 1989) of Atlas Software B.V. and Cordeo B.V. both two small software development companies in the printing industry.

Atlas Software B.V., is followed from 1992 up to the take over by Objectif Lune in 2004. By 2004 Atlas had 30 employees and produced software that optimizes printing workflows. Its main product was PrintShop Mail (PSM), a software 
package that is used for Variable Data Printing (VDP). This product is still sold by Objectif Lune.

Cordeo B.V. was followed from its establishment in 2001 up till 2008. At this moment Cordeo has 9 employees and provides marketing automation services to simplify the complexity of global marketing communication processes. Their XLdoc software Suite, is developed for the creation, management and ordering of documents.

Data collection

Data on the relationships of Atlas were collected in a retrospective way.

Relationship data of Cordeo were partly collected retrospective and partly in real time. For triangulation purposes we applied multiple data collection techniques, including interviews, desk research, participation in seminars and workshop and attending tradeshows. We also, as suggested by Miles \& Huberman (1994), cross-examined our findings with involved persons when the data or the results were ambiguous.

In the first stage, we studied literature on the printing industry (Matthyssens et al. 2004; Rose et al. 2002; Interguest 2001; European Commission 2005) and relation-specific documents such as contracts, financial overviews and websites. In the second stage, we conducted several semi-structured interviews with Harry Raaphorst, managing director of Atlas, and Cyril Reijnen, managing director sales \& marketing of Cordeo. In these interviews both directors were asked how their business developed, which companies have been relevant for the development and who had linked them to each other. Besides the managing directors we also interviewed partners and industry experts. Based on the interviews, we were able to visualize the network development of both companies (see figure 1 and 2 ) and to characterize their business development.

\section{Research context: the digital printing industry}

\section{Technological developments}

During the 1970s and 1980s laser printer technology developed and the first form of digital printing came available. The type of printing then was mainly black and white transactional printing and laser printers were directly attached to mainframe computers. In the 1980s, the rise of personal computers led to a need for a standardized printing language, and PostScript turned out to become the (defacto) industry standard, at least for promotional printing. Around 1990, Xerox launched its revolutionary DocuTech 135, a machine that contained the properties of a copier, but could also be connected to a computer network so that multiple users were able to share the same printer. Since then, Desktop Publishing took off, and virtually everyone could become a publisher; something that had always been preserved to the printing professionals. As a result, the commercial printing faced a decline in demand. Looking for opportunities for 
growth, the commercial printers realized they needed to search for value-added services and productivity gains by means of new technologies, faster make-ready and network digital workflows. However, digital (promotional) printing was initially quite expensive. Variable Data Printing (VDP) and Printing on Demand (PoD) were needed as a means to add value to paper and in that way to form a justification for the high printing costs. For short print runs, on-demand jobs, or personalization jobs, commercial printers choose to print digital, because digital is more cost-effective. Moreover, on offset presses personalization is not feasible and short and on-demand runs have too long turn-around times.

Central actors

A variety of companies are doing business in the digital printing network. To start with there are the large OEM's who produce digital printers, such as Xerox, Oce,Canon, HP, Xeikon. OEM's cooperate in technological platforms to develop technology in which ICT plays a large role. OEM's change their focus a product orientation to a demand orientation, with a development to full-service contract related to document management. A second group is the regional distributors who sell OEM printers. Their margins are under pressure because of the forward integration of OEMs. In search for added value they change to value added resellers (VARs). VARs sell OEM printers under their own brand and provide additional services such as consulting and installation. Danka, Ricoh, Nashuatec are examples of VARs. A third group are the printing companies, who face high price competition, consolidation and increasing production scale. New players with an ICT background enter the domain. In order to avoid price competition, printing firms seek new solutions for customer problems, such as offering digital solutions; printing firms who become logistic partners or focus on database and document management.

The two firms investigated are supplying software and services for different actors in the digital printing network. When in 1992 Atlas developed PrintShop Mail it was to solve the problems that printing house 'De Klomp' had with Variable Data Printing. As we will outline in more detail, later on OEM's were interested in PrintShop Mail as they argued that adding production software to their hardware was needed to increase printing volume. In 2001, Cordeo was ready with the development of the XLdoc Suite, a PoD software. Cordeo, however, did not position itself as a software supplier to OEMs, but as a consulting firm for document management and XLdoc as possible solution. Their customers are large corporations, commercial printing firms and consultancy partners. In the following we lay out the differences in business and network development of the two firms in more detail. 


\section{Analysis and Results}

Business and network development of Atlas

Over the years Atlas' business developed from providing customized software towards supplying specialized software for digital printing manufacturers and printshops. In alignment with this business development, Atlas' network developed in a worldwide sales network. Figure 1 visualizes the development of Atlas' network. Table 1 describes the strengths and heterogeneity of ties together with the intermediary functions at different phases of business development.

Legend

- OEM's

Distributors

- RIP vendors

Figure 1: Development of Atlas' actor network 


\begin{tabular}{|l|l|l|l|}
\hline & $\begin{array}{l}\text { Opportunity } \\
\text { discovery }\end{array}$ & $\begin{array}{l}\text { Opportunity } \\
\text { creation }\end{array}$ & $\begin{array}{l}\text { Opportunity } \\
\text { exploitation }\end{array}$ \\
\hline Time line & $1991-1992$ & $1992-2000$ & $2000-2005$ \\
\hline Focal relationship & $\begin{array}{l}\text { Drukkerij de } \\
\text { Klomp }\end{array}$ & $\begin{array}{l}\text { Drukkerij de } \\
\text { Klomp till 1995 } \\
\text { Xerox } \\
\text { RIP vendors } \\
\text { Other OEMs }\end{array}$ & $\begin{array}{l}\text { Xerox } \\
\text { Distributors }\end{array}$ \\
\hline Strength of Ties & weak & strong & strong \\
\hline $\begin{array}{l}\text { Heterogeneity of } \\
\text { Ties }\end{array}$ & high & medium & low \\
\hline $\begin{array}{l}\text { Intermediary } \\
\text { functions of focal } \\
\text { relationship }\end{array}$ & Not apparent & $\begin{array}{l}\text { Joining function of } \\
\text { de Klomp } \\
\text { Relating function } \\
\text { of Xerox and other } \\
\text { OEMs }\end{array}$ & $\begin{array}{l}\text { Relating function } \\
\text { Isolating function }\end{array}$ \\
\hline
\end{tabular}

Table 1: Characteristics of ties and intermediary functions along Atlas' path of business development

The stage of opportunity discovery started in 1991 when Drukkerij de Klomp, a Dutch printing firm, asked Atlas to solve their problems with the Xerox printer. As, at that time, Atlas made customized software for a diversity of customers, it operated in a heterogeneous network of weak ties. Harry Raaphorst, managing director of Atlas, expected that there would be more printing companies with the same problem, and saw an opportunity for new business development.

Raaphorst decided to focus his business on this particular problem. In this initial stage, in contrast to what we proposed, no intermediary functions were used. Based on De Klomp's specifications and requirements Atlas developed the product PrintShop Mail and established a joint venture with De Klomp to develop a customer base for this new product. So the new business idea generated from a close customer supplier interaction in which no intermediary was involved.

In the stage of opportunity creation, Drukkerij de Klomp joined Atlas to Xerox Netherlands, who was willing to bundle PrintShop Mail with newly sold printers, by which Xerox related Atlas' product to customers of Xerox. As Xerox was responsible for the sales of the product a strong relationship with Xerox developed. This relationship was focused on one product and one activity the selling of Printshop mail. However Atlas was also working with RIP ${ }^{1}$ vendors who develop technologies that covert the output instructions from programs such as PrintShop mail into a bitmap for every document that has to be printed. Through this cooperation Printshop Mail became an interface for various printing technologies and was developed both for the Macintosh and the Windows

\footnotetext{
${ }^{1}$ RIP stands for Raster Imaging Processing and converts the output instructions from programs such as PrintShop Mail into a bitmap for every document that has to be printed.
} 
platforms. These technological developments and the reputation of Xerox created opportunities to bundle PrintShop mail with the printing machines of other OEMs as well. So basically, Atlas was involved with two types of activities, with the OEMs the organized the sales and with RIP vendors they further developed the technological aspects of their product. For this reason we classified the heterogeneity of Atlas' ties as medium. In 1995 Drukkerij de Klomp was bought out: they realized that software development was not their competence.

In the stage of opportunity exploitation, the OEMs related PrintShop Mail to large clients, which provided access to extensive marketing infrastructures and possibilities to test software; however local users could not be reached with these partners. Therefore, Atlas further developed a world wide distributor network, relateting Atlas to local users all over the world. Atlas established strong relationships with OEMs and distributors for the purpose of selling its product. Because of a strong similarity of partners and a single focus on sales, therefore in this phase, we classified the heterogeneity of Atlas' ties as low. Furthermore, due to the increasing amount of users served via many OEM's and distributors, Atlas gets isolated from end users. In additional problem is that Xerox, Atlas' most important partner, does not seem to be willing to relate or join Atlas in new business development. For example, in 2004 with the rise of the Internet Atlas developed a web version of PrintShop Mail, Xerox did not support the web development. And, the web application was much less successful than the original PrintShop Mail.

The examination of intermediary functions and the visualization of Atlas' network development in Figure 1 indicate a development in which the amount of relationships with OEMs and distributors increase. The strong relationship with Drukkerij de Klomp disappears over time and so a close relationship with a lead user. Being disconnected from users rules out opportunities to learn about problems for which Atlas might develop new solutions. Also, one sees that the ratio between cross links and direct links decreases. The network gets the outlook of a portfolio of direct relationships. The description of Atlas' business development indicates an evolution into an efficient sales network with an important partner who is not willing to develop new business with Atlas.

\section{Business and network development of Cordeo}

While Atlas transformed its business from software engineering into supplying standard software and its network developed in a growth of rather similar partners, Cordeo focused on improvement of their XLdoc Suite and its network developed in a growth of varying types of customers and partners. The following section describes the co-development of Cordeo's network and business. Figure 2 visualizes the development of its network. Table 2, describes the strengths and heterogeneity of ties together with the intermediary functions at different phases of Cordeo' business development. 


\begin{tabular}{|l|l|l|l|}
\hline & $\begin{array}{l}\text { Opportunity } \\
\text { discovery }\end{array}$ & $\begin{array}{l}\text { Opportunity } \\
\text { creation }\end{array}$ & $\begin{array}{l}\text { Opportunity } \\
\text { exploitation }\end{array}$ \\
\hline Time line & $2000-2001$ & 2001-2007 & $2007-$ \\
\hline Focal relationship & Baan & $\begin{array}{l}\text { Direct customers } \\
\text { Print partners } \\
\text { Communication } \\
\text { consultancy } \\
\text { partners }\end{array}$ & $\begin{array}{l}\text { Direct customers } \\
\text { Print partners } \\
\text { Communication } \\
\text { consultancy } \\
\text { partners }\end{array}$ \\
\hline Strength of Ties & $\begin{array}{l}\text { Strong internal } \\
\text { ties }\end{array}$ & Strong/weak & Strong/weak \\
\hline $\begin{array}{l}\text { Heterogeneity of } \\
\text { Ties }\end{array}$ & $\begin{array}{l}\text { For external ties } \\
\text { high }\end{array}$ & $\begin{array}{l}\text { High (compared to } \\
\text { Atlas) }\end{array}$ & $\begin{array}{l}\text { High (compared to } \\
\text { Atlas) }\end{array}$ \\
\hline $\begin{array}{l}\text { Intermediary } \\
\text { functions of focal } \\
\text { relationship }\end{array}$ & Not apparent & $\begin{array}{l}\text { Joining Functions } \\
\text { Relating Functions }\end{array}$ & $\begin{array}{l}\text { Relating Functions } \\
\text { Isolating functions }\end{array}$ \\
\hline
\end{tabular}

Table 2: Characteristics of ties and intermediary functions along Cordeo' path of business development

The opportunity discovery of Cordeo started when Cyril Reijnen as marketing communication manager at Baan - an enterprise software solution firm with worldwide offices and customers - thought that there should be expertise in his firm to simplify the complexity of the global marketing communication process. For internal use at Baan the first version of the XLdoc software Suite was developed. Due to the expertise within Baan, XIdoc is strong in chain integration. When looking at the network surrounding this discovery one can say that is consisted of strong ties within Baan. Due to its divers customer base one could say that Baan was operating in a heterogeneous network. Their expertise with different industrial settings made possible the application of their software technology for solving the problem of the communication manager. Again in contrast to our proposition no intermediaries were involved.

The opportunity creation phase took off in 2001 when Baan got bankrupt, and Cyril Reijnen and Willem Stalknecht founded Cordeo; Cyril as managing director sales and marketing, and Willem Stalknecht as managing director ICT development. Cordeo provides marketing automation services, with XIdoc as PoD solution. The first customer was a business unit of DSM, a former employer of Cyril. In 2002, Infor, a restart of Baan, became the second customer. This second customer is again a former employer this time of both founders. Production capacity is provided by a printing firm. From 2004-2006, Cordeo implemented and expanded its Publish-on-Demand solution to all DSM business Groups worldwide. Their customer base further expanded with new corporations. Special non-exclusive applications were developed for different customers. 
Two different types of partners entered Cordeo's network, being print partners and print partners with consulting operations. Both these type of partners were looking for a good solution. They differ from the capacity providers in the sense that they make use of the solutions and services of Cordeo. Via the partners Cordeo served indirect customers and volumes started to grow exponential. Also, other capacity printers entered the network via the partners. Cordeo started to develop a more modular version of Xldoc in order to make implementation at customer firms of partners easier. When looking at the network of Cordeo in this phase, we could see heterogeneous ties in terms of the diversity of partners, which are both weak and strong. Strong ties not only exist in terms of exchange frequencies but also via XLdoc, which is highly integrated in the business process of customers. Focal relationships provide joining functions when bringing in Cordeo to solve customer problems. Also, relating functions are provided when partners bring in new users of $\mathrm{XI}-\mathrm{doc}$.

Legend:

- Combined print and consultancy partners

- Print partners

- Consultancy partners

Direct customers

- Indirect customers

Printers

Figure 2: Development of Cordeo's actor network 
In the opportunity exploration phase the partner network further expands, bringing more indirect customers and volume. Partners use their own capacity printers of which Cordeo is not always aware. Printers start to collaborate internationally with XLdoc as binding element. XLdoc is separately branded and positioned from Cordeo - Cordeo being the consulting firm and partner of printing firms and consulting firms and XIdoc the software firm, focusing on the development of applications. The repositioning of services and software are expected to reinforce growth. Except for the growth in ties, both weak and strong ties, as well as heterogeneous ties exist in terms of the diversity of partners. However in this exploitation phase isolating functions appeared, when partners use their own capacity printers.

Along the path of Cordeo' business development different partners fulfilled different intermediary functions, partners who provided isolating functions helped Cordeo to become more efficient and the partners with relating and joining functions helped Cordeo to stay flexible. Knowledge about customer needs is used to develop new applications, and a smoother implementation of their software. In this way Cordeo is flexible to develop new business and much less dependent on just one type of customer or partner.

\section{Cross case analysis}

A comparison between Atlas's and Cordeo's networking approaches offers a view of the mechanisms of business development in networks. It reveals similarities and differences between the firms in the focus of their network strategies and the ensuing business development. A first comparison between the two firms shows that both successfully exploited their business; however Cordeo was more successful in developing new business. Both firms developed an efficient network, which generated sales volume and through growth of new partnerships this sales increased exponential. For Atlas the close cooperation with Xerox had positive reputational effects, due to its relationship with Xerox other OEMs and Distributors easily started supplying PrintShop Mail. In addition to positive activity related network effects, Cordeo also managed to establish positive resource related network effects through using newly created applications in other relations. In order to guarantee transfer of solutions to other relations, Cordeo only worked on new applications if partners agreed with nonexclusive use of the created solution. Cordeo did not encounter any negative network effect so far. Atlas, however, did experience negative network effects. Despite many technological opportunities, Xerox is not willing to co-develop new solutions and share knowledge about new development. An explanation for this unwilling attitude of Xerox might be the moderate technological and business integration of PrintShop Mail in customer applications, the weak contact of Atlas with end users, and the isolating function of distributors and OEMs. Due to this network position Atlas has not been able to provide Xerox with interesting knowledge about adding value for customers and end-users. In comparison to 
Atlas, Cordeo's solutions provide high added value and are strongly integrated into the business process of both customers and partners. In this way Cordeo not only added value to its customers but also to a range of other players.

Furthermore, the integration into customer's business process provides Cordeo with knowledge about new developments and needs of different actors in the network - which gave Cordeo the opportunity to develop new business.

The following paragraph provides a more in depth examination of the intermediary functions that stimulated and constrained business development of Atlas and Cordeo, showing obvious parallels and striking differences. We compare the confirmation and disconfirmation in the two cases of our propositions. When discussing the propositions we elaborate further on how and why different intermediary functions of partners explain different outcomes in business development. Table 3 , shows a rather similar pattern in both cases, however a closer view reveals some differences both in terms of the extent to which different intermediary functions were used, as well as in relation to the type of activities for which the intermediary functions were used. A look at proposition 1 in Table 3 shows that in both cases intermediaries are not used for the purpose of opportunity discovery, in both cases business ideas arise from strong dyadic relationships.

\begin{tabular}{|c|c|c|}
\hline Propositions & $\begin{array}{l}\text { Confirmation in } \\
\text { Atlas case }\end{array}$ & $\begin{array}{l}\text { Confirmation in } \\
\text { Cordeo case }\end{array}$ \\
\hline $\begin{array}{l}\text { 1. Opportunity discovery is facilitated by } \\
\text { relating intermediaries. }\end{array}$ & - & - \\
\hline $\begin{array}{l}\text { Opportunity creation is facilitated by } \\
\text { joining intermediaries }\end{array}$ & + & + \\
\hline $\begin{array}{l}\text { Opportunity exploitation is facilitated } \\
\text { by isolating intermediaries. }\end{array}$ & + & + \\
\hline
\end{tabular}

Table 3: Comparison of conformation of propositions in the two cases.

When we look at proposition 2 in Table 3 we see that both firms used joining intermediaries for opportunity creation. But unlike Atlas, over time Cordeo keeps using joining functions, when partners join Cordeo to their customers to develop new applications. By loosing the joining function of Drukkerij de Klomp, Atlas is no longer involved in opportunity creation. When looking at proposition 3 , we see again a similar pattern; however Cordeo and Atlas used isolating functions in different ways. While Cordeo used the isolating functions in relation to production activities, Atlas used isolating functions of distributors and OEMs in relation to sales. In this way Atlas became isolated from the problems of end users and thus from new opportunity discovery.

The comparison suggests that different networking approaches drive business development. For successful business development both strong and varied ties 
as well as the existence of different intermediary functions of partners are necessary

\section{Conclusions}

In this paper we followed the dynamic alignment between networking approaches and business development of two small firms in the printing industry, with the aim to investigate how a small firm can maintain both its efficiency and flexibility in a business network. The comparison of the networking approaches, the network evolution and the accompanying business development of the two firms suggests that network approaches drive business development.

The findings suggest that joining functions of intermediaries are appropriate in opportunity creation, while isolating functions of intermediaries are appropriate in opportunity exploitation. These findings are in line with previous research on the importance of closed networks in innovation. However seen from a more dynamic point of view, this approach might generate an efficient business development but might hinder the flexibility to develop new business. Therefore, it seems important to foster relating and especially joining functions in the stage of opportunity exploitation. Further in contrast to what we proposed, in both cases no intermediary functions were used in the phase of opportunity discovery. Instead opportunities were discovered in close dyadic relationships, between customer and supplier. This is in line with the main industrial marketing literature, but contradicts with social network theory on the role of structural holes positions in generating knowledge benefits (Burt 1992).

In the case comparison we recognize some of successful networking strategies mentioned by Ford and Redwood (2005) and some others as well:

- Start to develop relationships before starting the firm

- Development of the firm will be successful if you start with a solution for a complex problem

- Chose to develop a network position with a broad and dense relationship pattern, to be able to recognize opportunities and threats

- Keep flexible by developing own technology in close relationship with customers but without exclusivity for the customer

- Keep flexible by providing added value to a variety of actors in the network

- Keep efficient by using the isolating functions of relationships

- Keep flexible by taking care that your relationship also fulfills relating and joining functions.

This paper is based on the assumption that our understanding of the co-evolution of networks and businesses might gain by following the business development of two small firms over 8-11 years. Most Industrial Networks studies focus on development of established relationships in networks, and not on the development of new firms and relationships, it seems as if the Industrial Network approach might be less suited for analyzing small, start-up firms which have possibly a few relationships. In the case of small firm start-ups, understanding of 
relationship development may be of more significance than in cases with relationship duration over several years. Similarly, in industrial settings characterized by some degree of path-breaking change, there may be a nonnegligible need for establishing relationships with new counterparts. And, as suggested by Dubois et al. (2003), changes in a firm's policy or technical modifications, or problems in an established relationship, may prompt the start up of new relationships. In any case, relationships seem to change, establish and develop along the path of business development. Therefore, in this paper we focused on the dynamic alignment between relationship and business development.

From the case studies we concluded that consciousness and understanding of intermediary functions helps a firm to position itself into its network in such a way that it can develop its business in new directions. Similar dynamics might be discerned when investigating resource interfaces (Araujo et al 1999; Dubois and Araujo 2005). As technological development is often driving new business development, further research into the role of resource interfaces seems relevant

\section{References}

Ahuja, G. (2000) Collaboration Networks, Structural Holes, and Innovation: A longitudinal Study. Administrative Science Quarterly, Vol 45, No 3, pp 425-455.

Anderson, J.C., H. Håkansson and J. Johanson (1994) Dyadic Business Relationships Within a Business Network Context, Journal of Marketing, 58, 115.

Anderson, J.C. and Narus J.A. (2004) Business Market Management: Understanding, Creating and Delivering Value (2nd edition) Uppr Sadle River, $\mathrm{NJ}$ : Pearson Prentice Hall

Araujo, L., A. Dubois, L.E. Gadde (1999) Managing Interfaces with suppliers. Industrial Marketing Management. 28: 497-506.

Benner, M. J., and M.L. Tushman (2003) Exploitation, Exploration, and Process Management: The Productivity Dilemma Revisited. Academy of Management Review, 28(2): 238-256.

Cook, K.S. and R.M. Emerson (1978), Power, Equity, Commitment in Exchange Networks. American Sociological Review, 43 (October) 721-738.

Dubois, A. et al. (2003) Change and continuity in the supplier base, Journal of Customer Behaviour, 2, 409-432.

Dubois, A., L. Araujo (2005) The Relationship between Technical and Organizational Interfaces in Product Development. The IMP journal. 1,nr1, 28-51. 
European Commission. (2005) ICT and Electronic Business in the Publishing \& Printing Industry. Sector Report No 03-11.

Faems, D., Van Looy, B. \& Debackere, K. (2005). Interorganizational collaboration and innovation; toward a portfolio approach. Journal of Product Innovation Management, Vol. 22, 238-250.

Ford D. and M. Redwood (2005) Making sense of network dynamics through network pictures: A longitudinal case study. Industrial Marketing Management. 34: 648-657.

Gadde, L.E., L.Huemer, H. Håkansson (2003), Strategizing in industrial networks. Industrial Marketing Management, 32: 357-364.

Granovetter, M. S. (1973). The Strength of Weak Ties. American Journal of Sociology, 78(6), 1360-1380.

Granovetter, M. S. (1982). The Strength of Weak Ties: A Network Theory Revisited. In P. V. Marsden \& N. Lin (Eds.), Social Structure and Network Analysis (pp. 105-130). Beverly Hills: Sage.

Groen, A.J. (2005) Knowledge intensive entrepreneurship in networks: Towards a multilevel/multi dimensional approach. Journal of Enterprising Culture, 13 (1): 69-88.

Håkansson, H (1989) Corporate Technological behaviour: Co-operation in networks, Routeledge, London.

Håkansson, H and I. Snehota (1995) Developing relationships in business networks. Routledge, London

Håkansson H. and A. Waluszewski, (2002) "Path dependence: restricting or facilitating development?" Journal of Business Research. vol. 55, pp. 561-570.

Håkansson H. and D. Ford (2002) How should companies interact in business networks? Journal of Business Research 55, 133-139.

Hoang H. and B. Antoncic (2003) Network bases research in entrepreneurship: A critical review, Journal of Business Venturing, Vol 18, 2, 165-187.

Holmen, E. (2001) Notes on a Conceptualisation of Resource-related embeddedness of Interorganisational Product Development. Dissertation, Southern Denmark Business School.

Holmen E. and A. Pedersen (2003) Strategizing through analyzing and influencing the network horizon, Industrial Marketing Management 32, 409-418. 
Interquest (2001), Digital Printing Market Potential 2001-2005, Graphic Arts Marketing Information Service, Alexandria VA.

Koza, M. P. \& Lewin, A.Y (1998). The co-evolution of strategic alliances. Organization Science. Vol. 9(3), 255-264.

Lee, J., J. Lee, J., and H. Lee (2003) Exploration and Exploitation in the Presence of Network Externalities, Management Science, 49(4): 553-570. March, J. G (1991) Exploration and Exploitation in Organizational Learning, Organization Science, 2(1): 71-87.

Matthyssens, P., K. Vandenbempt and L. Berghman (2004) Waardecreatie en innovatie in de industrie. Acco Leuven/Voorburg.

March, J. G. (1991). Exploration and Exploitation in Organizational Learning. Organization Science, 2(1), 71-87.

Miles, M. B., \& Huberman, A. M. (1994). Qualitative Data Analysis: An Expanded Sourcebook (Second ed.). London: Sage Publications.

Obstfeld, D. (2005) Social Networks, the Tertius Lungens Orientation, and Involvement in Innovation. Adminstrative Science Quarterly, vol 50. pp 100-130.

Rose, M. Striewe, F. and S. Müller (2002). The Horizon of Print \& Publishing Opportunities in the Media Economy of the $21^{\text {st }}$ Century. IBI Lisbon.

Rothaermel, F.T. \& Deeds, D.L. (2004). Exploration and exploitation alliances in biotechnology; a system of new product development. Strategic Management Journal, Vol. 25, 201-221.

Rothwell, R., \& Dodgson, M. (1994). Innovation and Size of Firm. In M. Dodgson \& R. Rothwell (Eds.), The Handbook of Industrial Innovation (Paperback 1996 ed., pp. 310-324). Cheltenham, UK, Brookfield, US: Edward Elgar Publishing Limited.

Shane, S. Venkataraman, S. (2002). The promise of entrepreneurship as a field of research. Academy of Management Review 25 (1), 217-226.

Snehota, I. (1990), Notes on the theory of business enterprise. PhD thesis Uppsala University, Department of Business Studies, Uppsala.

Soh, P.H. \& Roberts, E.B. (2003), Networks of innovators; a longitudinal perspective. Research Policy. Vol. 32, 1569-1588. 
Venkataraman, S. (1997) The distinctive domain of entrepreneurship research. In: Katz, J. (Ed.) Advances in Entrepreneurship: Firm Emergence and Growth. JAI Press, Greenwich, CT

Vlaar, P.W.L., F.A.J. Van Den Bosch and H.W. Volberda (2007) Towards a Dialectic Perspective on Formalization in Interorganizational Relationships: How Alliance Managers Capitalize on the Duality Inherent in Contacts, Rules and Procedures. Organization Studies, 28(04), 437-466.

Vossen, R. W. (1998). Relative Strengths and Weaknesses of Small Firms in Innovation. International Small Business Journal, 16(3), 88-94.

Yin, R.K. (1989) Case study research- design and methods. London Sage. 